\title{
Motivation and Learning Achievement of Economic Education Students, Faculty of Teacher Training and Education, University of Palangka Raya During the 2020 COVID-19 Pandemic
}

\author{
Sri Rohaetin, Kartini \\ Economic Education Study Program, University of Palangka Raya \\ Email: Sri.rohaetin@edu.upr.ac.id
}

Receipt: Nov, 12, 2021; Revised: Dec, 05, 2021; Accepted: Dec, 10, 2021

\begin{abstract}
This research is motivated by the learning motivation of students of the Economic Education Study Program FKIP Palangka Raya University during the COVID-19 pandemic. In compiling lecture assignments, each student has their learning methods and techniques, especially to achieve success in learning achievement. The purpose of this study is to determine the motivation and learning achievement of students of Economics Education FKIP Palangka Raya University during the COVID-19 pandemic. This study uses a qualitative approach, with a descriptive method. The results of research conducted at the Economic Education Study Program, Faculty of Teacher Training and Education, Palangka Raya University are about the motivation and learning achievement of Economic Education students, which indicated by the results of interviews that researchers have conducted, namely with the results of the research, most of the students of the Economics Education Study Program have high intrinsic and extrinsic motivation in achieving learning achievement. So, students have a strong willingness in carrying out learning activities. This can be seen from the average Economic Education students who got high Indeks Prestasi Semester or Grade Point Average (GPA) score from last semester, wherein the even semester of 2020/2021 lectures had used the online or online method.
\end{abstract}

Keywords: Motivation, Learning Achievement, Covid-19 Pandemic

\section{INTRODUCTION}

Education is one of the most basic factors in the cycle of human life, from birth to the end of life. In the National Education System Law No. 20 of 2003, Article 1 Paragraph (1) states that education is a conscious and planned effort to create a learning atmosphere and learning process so that students actively develop their potential to have religious-spiritual strength, self-control, personality, intelligence, noble character and skills needed by himself, society, nation, and state. According to Ki Hajar Dewantoro (UNJ LKM Creative Team, 2001:78) Education is "an effort to advance the development of character (inner strength), mind (intellect), and the body of children, in harmony with nature and society". This means that education aims to help students so they can improve and develop the potential that exists in themselves and as members of society in real life.

At the beginning of 2020, the world was on alert with a virus called the Corona Virus (COVID-19). The transmission of COVID-19 is so fast that the world 
health organization (WHO) designated this Coronavirus or COVID-19 as a Pandemic on March 11, 2020. This global epidemic status or pandemic indicates that the spread of COVID-19 is taking place so quickly that almost no country in the world can avoid the coronavirus. The Indonesian government has urged residents to stay at home and self-isolate. One of them is the Indonesian government implementing the PSBB rules which stand for Large-Scale Social Restrictions made in the context of handling COVID-19. This is done with the hope that the virus will not spread more widely with maximum healing efforts. In this social restriction effort, the Indonesian government has also limited activities outside the home such as educational activities that have been carried out through online learning.

The impact of COVID-19 has caused the economy in Indonesia to decline, the rupiah exchange rate dropped, the price of goods rose, especially medical equipment. This also has an impact on the education system in Indonesia. The result of the decision from the Minister of Education is that all learning activities both in schools and universities are carried out at their respective homes through the available applications. The Minister of Education issued Circular Letter Number 3 of 2020 concerning Prevention of Corona Virus Disease (COVID-19) to the Education Unit which stated that schools and universities were closed. (Kemendikbud RI, 2020). This is done to break the chain of the spread of COVID19, instead of learning activities being carried out online for all levels of education.

Palangka Raya University is one of the universities that implement this policy. With the Circular of the Chancellor of the University of Palangka Raya No. 11/UN24/LL/2020 concerning Prevention of the Development and Spread of Corona Virus Disease (COVID-19) in the University of Palangka Raya. One of the sounds of the circular letter is that face-to-face lectures are abolished and replaced with the Online Method or Online Learning. In the application of online learning, lecturers and students have their respective roles. Lecturers have roles as facilitators and mentors in learning activities, while students have roles as knowledge constructors, independent learners, and problem solvers. Online learning is done by utilizing technology, especially the Internet. Online learning is carried out using a distance learning system, where learning and teaching activities (KBM) are not carried out face-to-face. Learning is done using online methods such as WhatsApp, Email, Google Meet, ZOOM, and Google Classroom.

However, there is a disadvantage of online learning that students can become less active in conveying their aspirations and thoughts so that which can result in boring learning. A student who experiences boredom in learning will get no progress in learning outcomes. Therefore, it is necessary to encourage students to move students so that they are enthusiastic about learning so that they can have high learning achievements. As for the advantages of doing online learning, one of which is increasing the level of interaction between students and lecturers, learning can be done anywhere and anytime, reaching students (students) in broad scope, and facilitating the refinement and storage of learning materials. 
The spirit of learning can be owned by increasing motivation to learn. Learning motivation itself is a driving force or impetus that makes someone interested in learning so that they will learn continuously. Motivation is divided into two, namely Extrinsic Motivation and Intrinsic Motivation. Extrinsic motivation is a motivation that arises because of influences from outside the individual, it can be in the form of invitations, orders, coercion from others that influence a person to take an action. On the other hand, intrinsic motivation is a motivation that comes from within to take action without any external coercion. So if low motivation can cause low success in learning so that it will reduce student learning achievement, otherwise if motivation is high then success in learning will increase student learning achievement. Motivation plays a very important role in learning, with this motivation students become diligent in the teaching and learning process, and with that motivation, the quality of student learning achievement can be realized properly. High learning motivation is related to high learning achievement.

Economics Education students who experience Learning through the Online Method, many feel that learning with the Online Method is less effective because this learning is very dependent on the internet network connection that connects the lecturers and students, most of the students are in their hometowns, while in the village itself constrained by the network in each area, besides that it is constrained by internet quota. Many students complain about online learning because it drains the Internet quota. However, some of them have a high enough motivational spirit to keep learning by attending online lectures so that their achievements do not decrease.

\section{RESEARCH METHOD}

The approach used in this study is qualitative. According to Burhan Bugin (2003:42), the qualitative approach means research conducted to understand the phenomena of what is experienced by the research subject, for example, behavior, perspective, motivation, and so on as a whole and in the form of words and language at a time, natural special events. This means that the approach in this study does not use numbers.

This research took place in the Palangka Raya University campus area, precisely in Building P, Economic Education Study Program, Faculty of Teacher Training and Education. This location deserves to be used as a research location because researchers want to know the Motivation and Learning Achievement of Economic Education Students at FKIP Palangka Raya University in the middle of the 2020 COVID-19 Pandemic.

The data collection procedure aims to obtain relevant, accurate, and reliable data. Data collection methods used in this study are: Observation, Interview, and Documentation. Data analysis, in the early stages of data collection, the focus of the researcher was still wide and visible, while the observations were still general and broad. Data that has been organized into a pattern and made categories, then 
data is processed using the Miles and Huberman data model. The data that is deemed appropriate and to determine the focus and deepening of the data in the next data collection process. Data reduction, namely as a process of selection, focusing, abstracting, transforming rough data in which there is data, thus data reduction begins when the researcher focuses on the research area. Presentation of data, namely a series of information organization that allows research to be carried out. Presentation of the data obtained by various types, networks, activity linkages, or tables.

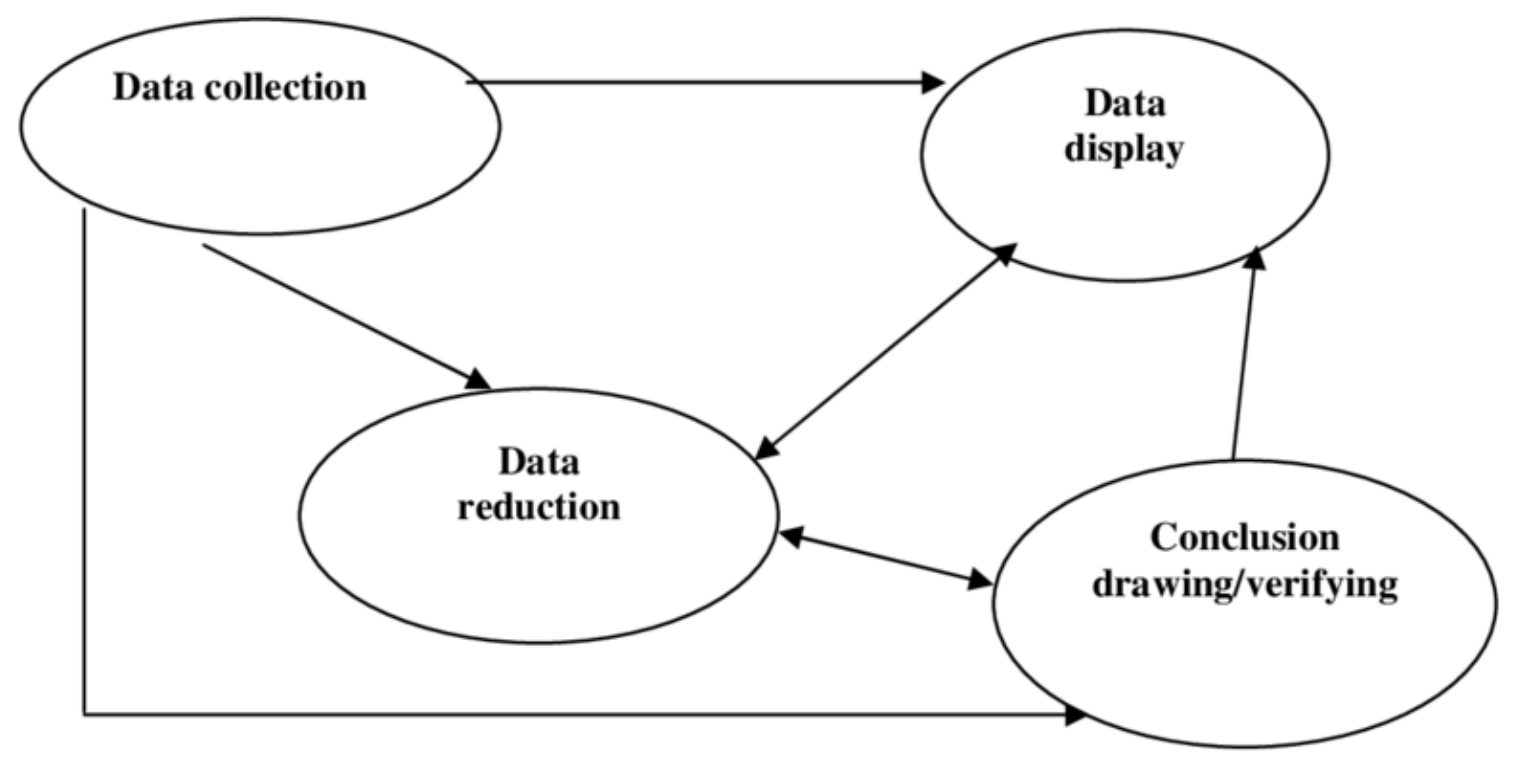

Figure 1. Interactive Data Analysis Model by Miles and Huberman

\section{RESEARCH RESULT AND DISCUSSION}

In connection with the results of interviews obtained in the field are as follows: 1. Do you have the desire and desire to succeed in achieving academic achievement? From the explanation of the informant above as a student of the Economic Education Study Program at the University of Palangka Raya class of 2017, 2018, and 2019 that the desire and desire to succeed in achievement is encouragement from within students. From some of the opinions that have been put forward that every student has the desire and desire to succeed in achieving his achievements.

1) In what way did you achieve success? The informants' answers to their questions are as follows:

From the explanation of the informants above as students of the Economic Education Study Program at the University of Palangka Raya batch 2017, 2018, and 2019, from several opinions that have been stated that the way to achieve success is by studying hard and persistently, remember with the aim that there is a desire and desire to achieve success. succeed in yourself, and again how to achieve that success by reading books looking for more references to add insight 
then being able to set study hours to be more structured besides that it is also necessary to have collaborative activities with friends so that success in learning can still be achieved but don't forget to always start by praying that everything you do will get maximum results.

2) What obstacles/struggles did you encounter in the process of achieving this success during this COVID-19 pandemic?

From the answer of the informants as students of the Economic Education Study Program class 2017, 2018, and 2019, the obstacles/obstacles found in the process of achieving success during the COVID-19 Pandemic where the learning process is carried out online or online there are obstacles to the learning process including namely quota, signal, and internet network because most students return to their hometowns and the network is mostly inadequate. From some of the opinions that have been collected, students feel that the obstacles /struggles are found interfere with the online learning process, with the limitations of online learning, students are not satisfied with the Q\&A in the Classroom discussion forum because many questions are piled up by other friends' questions, so questions submitted is not discussed or answered by the lecturer. Then the extravagant quota of students feels that it is a burden in itself and if there is no network, students are willing to travel long distances to get a signal and Internet network so that the learning process can still be achieved optimally.

3) What Efforts Will You Make To Overcome Obstacles / Barriers In Increasing Your Learning Motivation During the COVID-19 Period? The informants' answers to their questions are as follows:

From the explanation of the student informants of the Economic Education Study Program class 2017, 2018, 2019 that efforts to overcome obstacles/obstacles in increasing learning motivation during the COVID-19 pandemic are by looking for solutions and asking seniors who have taken the course to ask if do not understand the material explained by the lecturer who is poorly understood because of the limited time of the online learning process using Google Meet and ZOOM. From several opinions, those stated that the effort that can be overcome is to find an adequate internet network so that information about coursework is not left behind, then information with course schedules that can be moved forward and can also be delayed due to unwanted matters. By looking for signals and internet networks, even though the distance traveled is very far, they still have high enthusiasm, in addition to increasing the motivation to learn is high during the Covid-19 pandemic, namely by reading books and references on the internet.

4) In your opinion, how to generate high interest in learning during this COVID19 pandemic? The informants' answers to the questions are as follows:

From some of the opinions of informants from students of the Economic Education Study Program at the University of Palangka Raya batch 2017, 2018, 
and 2019 that the way to increase the interest in learning during the covid-19 pandemic is first by liking the courses taken, because if we like the courses, later we will be automatically interested in learning which will increase the freshness of mind to fully concentrate on learning. The tasks are given by the lecturer can gain students' interest in learning to start the subject, which later must be supported by a learning atmosphere that fun and not boring.

5) What facilities do you need to support your learning success during this COVID-19 pandemic? The informants' answers to these questions are as follows:

From the answers of several informants from the Economics Education Study Program at the University of Palangka Raya, class 2017, 2018, and 2019 that facilities that can support successful learning are still achieved, namely laptops, books, cellphones, Wi-Fi or internet quota with good internet network, due to the COVID-19 pandemic learning processes using online or online so there are no longer face-to-face lectures like before. To reduce the spread of the virus, schools and even universities have changed the learning process to online which can be carried out anytime and anywhere using a SmartPhone as long as there is an internet network and quota, so the learning process will run smoothly.

6) If the facilities you need to support the learning's success are not available, how do you plan to keep your learning success achieved? The informants' answer to this question is as follows:

From the presentation of informants from the Economics Education Study Program at the University of Palangka Raya, class 2017, 2018, and 2019, stating that if the facilities needed are not available, the way to make it work is by looking for rentals to do assignments, other than by studying together with friends or working in groups. Adequate facilities needed to be able to share the facilities so that learning success can still be achieved. If the internet network is not available in the village, the student will look for a place where there is an adequate internet network, even if the place has to be traveled a long distance. The student will still look for it so that learning success is achieved, and is not left behind with other friends in the city who have a good network.

7) What are your hopes for achieving your goals in the future? Informants' answers to this question are as follows:

From the answers of informants from the Economic Education Study Program at the University of Palangka Raya, class 2017, 2018, 2019, the hope in achieving future goals is to have a smooth process in learning, so the result of the efforts is a success, then to be able to study more with no limit. In which the goals want to be achieved smoothly.

8) What are your motivations or demands to achieve your goals?:

From the explanation of the informant above as students of the Economic Education Study Program at the University of Palangka Raya class of 2017, 2018, and 2019, that the strongest encouragement to achieve their goals is their 
parents. With the desire to make parents and family happy, the strongest impulse appears to be proud, as well as being a good example for younger siblings. Then the biggest encouragement is also Intrinsic motivation, namely, from within the desire to succeed and become a successful person through education first, by studying as high as possible to be equal with other friends. Education is a very important human need because education has the task of preparing human resources (HR) for the development of the nation and state.

9) From Learning Achievements, Do You Want Rewards In Learning? And what kind of rewards do you want

From the answer of informants from the Economic Education Study Program at the University of Palangka Raya, class 2017, 201.8, and 2019 stated that, from learning achievements, there is the desired award, such as a high GPA score. Some informants want a certificate of appreciation for outstanding students because it increases the value for students who get it. The certificate itself is very valuable to make it easier for them to get a job. To encourage them to be even more enthusiastic in learning, then the appreciation given can be seen by friends. So, the friends around the student may follow the student's achievement by seeing his/her hard work.

10) In What Way Can You Achieve Rewards In Learning?

From the presentation of student informants of the Economic Education Study Program at Palangka Raya University class 2017, 2018, and 2019 explaining that if learning activities start to get boring, the activities to eliminate the boredom, especially during the COVID-19 pandemic, namely stopping for a moment to refresh the brain by listening to songs. Also look for other activities or activities such as playing games or cooking, so that boredom in learning can disappear if the student is fit again then he/she can continue learning and the brain can accept the material being learned.

11) How do you create a conducive learning environment so that it is possible for you to study well, especially the learning environment at home or in a boarding house?

From the informants of the Economic Education Study Program students at the University of Palangka Raya class 2017. 2018, and 2019, most respondents said that the way to create a conducive learning environment to possibly study well, especially at home or in a boarding house, is to find a safe and quiet place. away from the noise to focus on studying. Then the atmosphere around must be cool, clean and tidy. Try to keep things that can interfere with studying temporarily away.

Based on the results of interviews conducted by the author with the students of class 20172018 and 2019, in which the instruments were only taken 3 (three) students with a total number of 9 (nine) students interviewed by the author. The research was conducted for 3 (three) months in the Economic Education Study 
Program by conducting direct and indirect interviews. Most of the students were interviewed through WhatsApp due to the COVID-19 pandemic, as the students who were in their hometowns could not be met directly. Therefore researchers used Whatsapp Chat for interviews to keep the research process going. In addition, the authors also conducted observations and documentation to complete the data needed for the next stage of research.

In the beginning, before the orientation, the researcher gave a research letter to the Economics Education Study Program to ask permission to research the 2017, 2018, and 2019 students. After obtaining permission from the Economics Education Study Program, the researcher contacted the students who would be interviewed to ask for permission and enter into an agreement. to be able to conduct interviews. After getting permission from the informant, the interview was carried out directly or indirectly (via WhatsApp) depending on the agreement of the informant because most of the informants asked for research were in their hometowns. So, it is not possible to conduct the interview face-to-face.

Based on the results of research conducted on students of the Economic Education Study Program at the University of Palangka Raya from the class of 2017, 2018, and 2019 with a total of 9 (nine) student informants about student motivation and learning achievement during the COVID-19 pandemic, the results showed these:

1) Intrinsic Motivation, namely:

There is A Desire And Willingness to Succeed

Students who are motivated both internally and externally inactivity will have the desire and willingness to succeed in achieving learning achievements. By being active in learning and being able to seek knowledge from other reference sources, which do not only rely on the knowledge provided by the lecturer.

There is Strong Will and Necessity to Learn

The need for learning will make students have a strong drive to get what they need in learning so that their learning motivation is also high in carrying out these activities. Then with encouragement, because they want to succeed and be successful, students will always pay attention to the lecturer's explanation in explaining the material given, because the feeling of the need for knowledge can be obtained from the lecturer.

There is hope or aspirations for the future

Students who are motivated towards something must have certain goals or ideals that move them to always carry out these activities until their goals are actually realized, and the results of research from several informants that all students have different hopes or aspirations for the future. They are different but in the process of achieving the same. Thus, the students must be active in learning and try to always be active in the class.

2) Extrinsic Motivation, namely: 
There is an appreciation in learning

Students who are motivated in a learning achievement will have a sense of pride in themselves when students are successful in achieving achievements. And the results of the research that some students want an award in learning such as a certificate of appreciation for students who excel because it will create more value for students who get it. Some students want an award only to hope for congratulatory appreciation from lecturers and friends to encourage them to be more enthusiastic in learning, and it is hoped that students who have not achieved learning achievements can be encouraged and motivated.

There are Interesting Activities in Learning

Students who are motivated in the activity will look for interesting activities in learning, the way to make it not boring at the time of learning is to change the previous monotonous learning activities to be more interesting and fun. It is hoped that by creating interesting and fun learning, meaningful learning will be achieved for students.

The Existence of a Conducive Learning Environment, Allowing a Student to Study Well

Students who have the motivation to learn will be able to easily create a conducive learning environment because there is a serious intention in achieving success. With a conducive learning environment, students' concentration will be full and quickly and easily absorb the knowledge that students learn.

Motivation and learning achievement are two related things. And students who have intrinsic and extrinsic motivation will certainly have a higher drive to achieve success in learning. Where all students also have the desire and willingness to succeed in achieving learning achievements during the 2019 COVID-19 pandemic, with various ways to achieve them. Even though there are obstacles or struggles faced in the learning process through online methods or online lectures, students will try to keep facing and finding solutions to some of the existing obstacles. The extravagance of Internet quotas and the difficulty of the Internet network in our hometown are obstacles that students often experience and feel. Because quotas and internet networks are very important factors so that the learning process is carried out properly. So, to overcome the obstacles/struggles, most students will look for places where there is an adequate internet network signal.

Learning motivation is a connecting bridge in achieving learning achievement. This is shown by the results of research, most students who have a strong motivation get a high IPS (Achievement Index) score from last semester. With a good interest in learning as well as encouragement or demands to achieve goals and want to get an award from learning achievements, the enthusiasm of students is not broken even though the learning process uses online methods or online lectures that are no longer face-to-face lectures. This can be seen in Table 5. 
Table 5

Informants' Gpa Score

\begin{tabular}{|c|c|c|c|c|c|}
\hline No & Name & Class & $\begin{array}{c}\text { V Odd } \\
\text { Semester } \\
\text { Score }\end{array}$ & $\begin{array}{c}\text { VI } \\
\text { Even } \\
\text { Semester } \\
\text { Score }\end{array}$ & Predicate \\
\hline 1 & Edi Junawan & 2017 & 3,47 & 3,35 & Very good \\
\hline 2 & Victor Ratu Ester & 2017 & 3,86 & 3,83 & Excellent \\
\hline 3 & Dewi Agustina & 2017 & 3,63 & 3,53 & Excelllent \\
\hline No & Name & Class & $\begin{array}{c}\text { III Odd } \\
\text { Semester } \\
\text { Score }\end{array}$ & $\begin{array}{c}\text { IV Even } \\
\text { Semester } \\
\text { Score }\end{array}$ & Predicate \\
\hline 4 & Selly Mistavia & 2018 & 3,70 & 3,77 & Excellent \\
\hline 5 & Herlina Safitri & 2018 & 3,4 & 3,63 & Excellent \\
\hline 6 & Friska Anugrahni & 2018 & 3,58 & 3,91 & Excellent \\
\hline No & Name & Class & $\begin{array}{c}\text { I Odd } \\
\text { Semester } \\
\text { Score }\end{array}$ & $\begin{array}{c}\text { II Even } \\
\text { Semester } \\
\text { Score }\end{array}$ & Predicate \\
\hline 7 & Windi Freza & 2019 & 3,44 & 3,5 & Very good \\
\hline 8 & Nini Karlina & 2019 & 3,41 & 1,08 & - \\
\hline 9 & Wenny Awalia & 2019 & 3,35 & 3,7 & Excellent \\
\hline
\end{tabular}

Data Source: Informants' Report Cards of Economic Education Students, University of Palangka Raya

It can be concluded from Table 5 that the report cards obtained by even semester students, five (5) out of nine (9), of whom got a high Indeks Prestasi Semester or Grade Point Average (GPA) score with a GPA score $>3.5$ increased from the previous semester, and four (4) of them get a declining GPA score. This is due to the various obstacles faced. One of the most influential obstacles is the inadequate network in students' hometowns, and from the IT team itself, Server Down often occurs, namely the failure of a system where the server experiences a failure that causes the server to be inaccessible. Many students have difficulty entering the Final Semester Exam Website so that the exam process is disrupted, and many students are unable to complete the exam questions because they run out of time. So this has an impact on the value of the Ujian Akhir Semester (UAS) of Final Semester Examination which is not optimal.

The average value of the GPA (Gradual Achievement Index) of Economic Education students starting from the 20172018 and 2019 batches can be seen in Table 6.

\section{Table 6}


Average Score Of Indeks Prestasi Kumulatif (Ipk) Or Cumulative Grade Point Of Students Of Class 2017, 2018, And 2019

\begin{tabular}{|c|c|c|c|}
\hline No & Class & $\begin{array}{c}\text { Average Score of Indeks } \\
\text { Prestasi Komulatif } \text { (IPK) }\end{array}$ & Predicate \\
\hline 1 & 2017 & 3,16 & Excellent \\
\hline 2 & 2018 & 3,23 & Excellent \\
\hline 3 & 2019 & 3,26 & Excellent \\
\hline
\end{tabular}

Data Souce: Scores are collected from the administrative staff of the Economic

Education Study Program

\section{CONCLUSION}

Based on the description and presentation of the research results that the researchers presented in the previous results, with the title "Motivation and Learning Achievement of Students of the Economic Education Study Program, FKIP University of Palangka Raya in the Middle of the COVID-19 Pandemic", several conclusions can be drawn, namely:

From the results of research conducted at the Economic Education Study Program, University of Palangka Raya, it can be concluded that every student has the intrinsic motivation and extrinsic motivation, namely the desire and desire to succeed in achieving learning achievement, in various ways, one of which is active in learning to achieve successful learning achievement. Despite the various obstacles or obstacles faced by students with learning through the Online Method or Online lectures, students will find solutions to the obstacles they face. One of the obstacles faced is the internet quota and internet network for students who are in their hometown. However, these obstacles are not an obstacle for students to achieve learning success. Students will look for a place where the signal and internet network are adequate so that the learning process can still be achieved optimally. In addition, the motivation of students to want to succeed is due to a strong urge from themselves to make their parents and family happy so that they are no longer looked down on by others. Therefore, with a strong motivation, the willingness to succeed is also very high.

\section{REFERENCES}

Ai, T., Yang, Z. and Xia, L. (2020) Correlation of Chest CT and Rt-PCR Testing in Coronavirus Disease, Radiology, 2019, pp. 1-8. Doi:10.1435/PERS.80.2.000.

A.M, Sadirman. (2010). Interaksi dan Motivasi Belajar Mengajar. Jakarta: Rajawali Pers 
Arikunto, Suharsimi. (2006). Prosedur Penelitian Suatu Pendekatan Praktis. Jakarta : Rineka Cipta

Dalyono, M. (2009). Psikologi Pendidikan. Jakarta : Rineka Cipta

Dantes, Nyoman. (2012). Metode Penelitian. Yogyakarta: Andi Offset

Hipjillah, A. (2015). Mahasiswa Bekerja Paruh Waktu: Antara Konsumsi Dan Prestasi Akademik, Jurnal Ilmiah, Dipublikasikan: Universitas Brawijaya, Malang.

Jihad, Asep dan abdul Haris. (2009). Evaluasi Pembelajaran. Yogyakarta:Multi Pressindo

Mohammad Surya. (2004). Psikologi Pembelajaran dan Pengajaran. Bandung: PT Remaja Rosda Karya

Oemar, Hamalik. (2011). Proses belajar Mengajar. Jakarta: Bumi Aksara.

Sadirman A.M, (2012). Interaksi dan Motivasi Belajar-Mengajar. Jakarta: PT Raja Grafindo Persada

Sugiyono (2016). Metode Penelitian Kuantitatif Kualitatif dan R\&D. Bandung : Alfabeta

Sugiyono (2015). Metode Penelitian Kombinasi (Mix Methods). Bandung: Alfabeta Sugihartono, dkk. (2007). Psikologi Pendidikan. Yogyakarta: UNY Press.

Uno. H.(2011). Teori Motivasi dan Pengukurannya. Jakarta: PT Bumi aksara Bandung PT Remaja Rosdaka Karya 